\title{
THE EFFECTS OF SEEDING RATE AND ROW SPACING ON THE PHOTOSYNTHETIC ACTIVITY OF SOYBEAN (GLYCINE MAX (L.) MERR.)
}

\author{
MikheeVA, O. ${ }^{1}-$ KlymenKo, I. $^{2}-$ Mikheev, V. ${ }^{1 *}$ - Golovan, L. $^{1}-$ DychenKo, O. ${ }^{3}-$ \\ STANKEVYCH, S. ${ }^{1}$ - CHECHUI, H. ${ }^{1}-$ LASlO, O. ${ }^{3}-$ CHUPRYN, Y. ${ }^{1}-$ NAHORNA, S. ${ }^{3}$ \\ ${ }^{1}$ Kharkiv National Agrarian University nd. a. V. V. Dokuchaev, Kharkiv 62483, Ukraine \\ ${ }^{2}$ Plant Production Institute nd. a. V. Ya. Yuriev of NAAS, Kharkiv 61000, Ukraine \\ ${ }^{3}$ Poltava State Agrarian Academy, Poltava 36000, Ukraine \\ *Corresponding author \\ e-mail:mixeev.valentin@outlook.com
}

(Received $2^{\text {nd }}$ Jun 2021; accepted $3^{\text {rd }}$ Sep 2021)

\begin{abstract}
With an advent of early-maturing soybean varieties that have weaker ability to branch, there is a need to study the increase in seeding rates with different combinations of row spacing, in order to determine the effects of narrowing the area of plant nutrition on photosynthetic plant activity. This is the purpose of our research. The multifactorial experiment was performed by splitting sites in four replications. The research has demonstrated that the Baika variety sown with a row spacing of $15 \mathrm{~cm}$ and a seeding rate of 1.2 million pcs./ha -40.5 ths. $\mathrm{m}^{2} / \mathrm{ha}$ was close to the optimal leaf surface. The Annushka soybean plants were inferior to variety Baika in this regard, with the difference up to 6.0 ths. $\mathrm{m}^{2} / \mathrm{ha}$, due to differences in the leaf structure of the soybean varieties. The weather conditions have been found to play the dominant role; namely, a strong direct correlation was found between the amount of precipitation and the photosynthetic productivity of plants. For the Annushka variety, it was in the range of $r=0.714 \ldots$ 0.843 , and for the Baika variety, $r=0.899 \ldots 0.947$. Thus, using different combinations of seed sowing rate and row spacing, it is possible to adjust the photosynthetic productivity of soybean plants and, as a result, to provide better conditions for their development and higher yields.
\end{abstract}

Keywords: soy bean (Glycine max (L.) Merr.), leaf areas, seeding rate, sowing method, correlation

\section{Introduction}

The area of soybean (Glycine max (L.) Merr.) crops in Ukraine has already reached 1.84 million hectares, the top position in Europe, and the soybean production amounts to 3,688.3 thousand tons ranking the country the eighth producer worldwide (Drobitko, 2007; State Statistics Service of Ukraine, 2019). This progress is due to a number of factors including the development of new varieties, the improvement of cultivation technologies and the growing demand for crops in the market. However, the yield of $2.4 \mathrm{t} / \mathrm{ha}$ remains low and far from the highest observed for this crop, which is $11.5 \mathrm{t} / \mathrm{ha}$ (Yilmaz, 2003; Ogurtsov et al., 2016; Rozhkov et al., 2021).

Soybeans, similarly to most crops, provide a yield of $2-6 \mathrm{t} / \mathrm{ha}$ using only $0.5-1.5 \%$ of photosynthetically active radiation (PAR) (Nichiporovich et al., 1969; Purcell et al., 2002; Amelin et al., 2011). Meanwhile, by selecting the optimal sowing rates and sowing methods, it is possible to increase this value up to $4-5 \%$, which will bring the yield to the highest possible of 10-15 t/ha (Amelin et al., 2011; Fontana et al., 2012).

Photosynthesis is the main factor in the formation of $90-95 \%$ of dry matter (Nichiporovich et al., 1969; Babych and Tkachuk, 2003; Baranov and Ugo Toro Korrea, 2006; Drobitko, 2007; Borovoj and Belik, 2009; Chuprina et al., 2021a). Up to $45 \%$ of 
dry matter is composed of carbon, which is assimilated by the plant due to solar energy (Nichiporovich et al., 1969). The efficiency of photosynthesis under experimental conditions could reach $25 \%$, and in the field it is $2.5 \%$ or lower (Sims et al., 1998). This is accounted for by a number of reasons, the majority of these being the insufficient supply of mineral nutrition and water for plants, inadequate selection of the optimal plant density, and the premature loss of leaf surface (Silva et al., 2013; Ribeiro et al., 2017). Therefore, the formation of high and sustainable productivity of soybean crops largely depends on the intensity of this process (Babych et al., 2003).

All legumes, including soybeans, are $\mathrm{C}_{3}$-plants (Hikosaka and Terashima, 1995; Ogurtsov et al., 2016; Golovan et al., 2019). Plants of this type are characterized by slow leaf formation and low-rate growth for almost thirty days after seedling emergence. There is also increased abortion of flowers and beans, poor resistance to shading, the need for high concentrations of carbon dioxide along with optimal insolation and temperature, increased respiratory activity and, as a result, unproductive dry matter consumption (Leshhenko, 1962; Miyazawa et al., 1998; Chuprina et al., 2021b).

Scholars have found that the optimal conditions for photosynthesis were achieved when the leaf surface increased rapidly at the beginning of the vegetation period to its maximum size and was maintained for a prolonged period of time. Soybean plants have the maximum size of their leaves over the period of flowering and bean formation (BBCH 67-77) (Abaevet et al., 2009; Ribeiro et al., 2017). With the higher stocking density of soybean plants the leaf index of sowing is increasing, while the leaf area of one plant is decreasing (Babych et al., 2003; Procópio et al., 2014; Balbinot et al., 2015). However, the latter decreases at a slower rate than the increase in plant density (Gureeva and Xramoj, 2009).

Leaves also function as an organ of transpiration. The leaf surface area of 40.000 to $50.000 \mathrm{~m}^{2} / \mathrm{ha}$, in order to absorb up to $90 \%$ of light energy, should have easily accessible moisture of at least $20-50 \mathrm{~m}^{3} / \mathrm{ha}$ per day. Therefore, increasing the area over 60.000 to $70.000 \mathrm{~m}^{2} /$ ha or higher is a negative factor that affects getting high crop yields considering the impeded light access to the crops and, accordingly, the reduced photosynthesis productivity (Nichiporovich et al., 1969; Sauer et al., 2007; Chuprina et al., 2020). The activity of the leaves at different tiers and over different periods of growth and development varies. At the initial stages of soybean plants growth their leaves direct the accumulated dry matter primarily to the roots and the growing parts of the stem (Leshhenko, 1962; Kokubun, 1988). New leaves receive products of photosynthesis from the old ones while the former have a small working surface. With the advent of fruit, the movement of dry matter is redirected to the beans where it is distributed between the leaves and seeds. The upper leaves remain underdeveloped; all the growth processes are slowed down, and then stop completely (Ogurtsov, 2008). During this period, the dry matter is not transported from one leaf to another in the lower, shaded tier; the leaves are starving, and this fact accounts for their premature falling off in the lower tier (Leshhenko, 1962; Ono et al., 2001). The typical feature of soybean plants is that the leaves provide nutrition only for those beans that are located in their axils (Kizilova, 1974; Calmeset et al., 1988). This is the reason of the bean loss after the leaf loss in the corresponding node, which is easily noticed in thickened crops (Leshhenko, 1962). However, the photosynthetic ability of the leaves located in different parts of the plant varies; thus, the nutrition of beans in the upper and lower tiers differs (Kizilova, 1974), and the quality of the seeds formed in the fruits located in different places varies considerably (Ogurtsov et al., 2016). 
The photosynthetic potential (PP) of soybeans depends significantly on the location of the leaves on the plant, the length of the day, the intensity of solar insolation, temperature and humidity, water supply, nutrients, etc. (Ogurtsov et al., 2016). The most active PAR absorption by leaves of plants occurs in the morning and afternoon hours. At noon, a pronounced decline in photosynthesis activity, at the average of $40 \%$, is observed (Cunha and Volpe, 2010; Amelinet et al., 2011). The size and dynamics of PP throughout the growing season are dependent not only on varietal characteristics and the phase of plant development, but also on the soybean technology features (Zherebko et al., 2003; Ivebor, 2006). The highest values of PP were observed in years of high precipitation, and the lowest in those with dry seasons (Medvedeva and Babarykina, 2011).

Net productivity of photosynthesis (NPP) varies depending on the cultivating conditions; the dynamics during the growing season in soybean plants is sinusoidal (Dziubailo and Myhal, 2011; Myhal, 2011). It has the form of a two-vertex curve with peaks in the phases of branching and fruiting (BBCH 21-29 and BBCH 70-79) (Babych et al., 2003). Thus, soybeans have the highest indicators of NPF during the period from branching to the beginning of flowering (from BBCH 21-29 to BBCH 60-64) (Babych and Tkachuk, 2003).

In sparse crops, where conditions for the photosynthetic operation was better, the net productivity of photosynthesis was higher. Therefore, the maximum grain yield from each plant was observed. However, the actual yield of soybean grain per unit area at such a plant density was insignificant. On the other hand, in thickened crops, where the NPP was lower, the yield of soybeans from one plant decreased significantly (Babych et al., 2003).

Increased leaf surface area and photosynthetic potential results in a decrease in the productivity of photosynthesis (Babych and Tkachuk, 2003). The correlation between these indicators is negative $(r=-0.81, d=0.66)$ (Babych et al., 2003). This depends on the activity of the leaves of different tiers, and the uneven distribution of light to them. In the leaves of the lower tiers, due to shading, the intensity of photosynthesis is considerably reduced, which affects the supply of beans located there with the necessary substances. Therefore, they are defective or fall off. This is especially evident in thickened crops, in which the yield is reduced due to fewer beans and their lower weight (Andreyuk, 2010; Ribeiro et al., 2017).

Sowing rates and sowing methods are important or the formation of the leaf surface area of crops and the efficiency of their use. Ensuring their more uniform distribution and optimizing the feeding area of each plant enables to achieve maximum efficiency of their functioning and the assimilation of a larger share of photosynthetically active radiation (Mizerna and Nosulia, 2016; Ogurtsov et al., 2016).

Therefore, the research on the response of new modern soybean varieties to different plant density rates becomes apparent. The aim of this study is to evaluate the impact of the three sowing methods and five seeding rates on the photosynthetic productivity of plants in soybean varieties of different maturity groups.

\section{Materials and methods}

The research was conducted over the period of 2015-2018 in the field of the grain steam-row crop rotation of the Department of Plant Breeding of Kharkiv Dokuchaev NAU, Ukraine (latitude $49.893815^{\circ}$, longitude $36.449448^{\circ}$ ). The soil of the 
experimental field is chernozem, a typical deep heavy loam on forest carbonate. The content of humus in the arable layer is 4.4-4.7\%, mobile phosphorus - $13.8 \mathrm{mg}$, potassium - $10.3 \mathrm{mg} / 100 \mathrm{~g}$ of soil (Tikhonenko and Degtyarev, 2016).

The format of the three-factor field experiment applied was as follows. Factor A: soybean varieties (two variants) - Annushka (very early-ripening variety 0000) and Baika (early-ripening variety 000); factor B: sowing methods (three options): 1 -a row having a $15 \mathrm{~cm}$ spacing; 2 and 3 - wide-row with a row spacing of 45 and $70 \mathrm{~cm}$; factor C: seed sowing rate (five options): 0.8, 0.9, 1.0, 1.1 and 1.2 million pcs./ha. The experiment was based on the method of split sites, in four replications. Areas of the first order are varieties; the second order includes sowing methods; the third order - seeding rates (Rozhkov et al., 2016). The phases of development were determined visually according to the international classification $\mathrm{BBCH}$ (Biologische Bundesanstalt für Land- und Forstwirtschaft, Bundessortenamt und CHemische Industrie, in German) (Meier et al., 2011).

The evaluation of photosynthetic activity was performed based on the following indicators: the leaf surface area, photosynthetic potential, and the net productivity of photosynthesis. The area of the leaves was determined by the method of "cutting off": the leaves of the sample were weighed with the accuracy to the second decimal value; a spanner of a preset diameter was used to make cuts. With the mass and area of cuttings and the total weight of the leaf determined, the area of the leaf was calculated using Equation 1:

$$
\mathrm{s}=\frac{\mathrm{M} * \mathrm{~s}_{1} * \mathrm{k}}{\mathrm{m}}
$$

where: sis leaf area, $\mathrm{cm}^{2} ; \mathrm{M}$ - the total weight of the leaf, $\mathrm{g} ; \mathrm{S}_{1}$ - the area of one cut-off, $\mathrm{cm}^{2} ; \mathrm{k}$ - the number of cuts, pcs; $\mathrm{m}$ - mass of cuts, g (Nichiporovich et al., 1969; Rozhkov et al., 2016).

The photosynthetic potential was determined by Equation 2:

$$
\mathrm{PP}=\frac{\left(\mathrm{S}_{1}+\mathrm{S}_{2}\right) * \mathrm{~T}}{2 * 1000}
$$

where: PP - photosynthetic potential, million $\mathrm{m}^{2} /$ ha per day; $\mathrm{S}_{1}, \mathrm{~S}_{2}$ - leaf area at the beginning and end of a certain period (development phase), ths. $\mathrm{m}^{2} / \mathrm{ha}$; $\mathrm{T}$ - duration of the period, days (Nichiporovich et al., 1969; Rozhkov et al., 2016).

The net productivity of photosynthesis was determined using Equation 3:

$$
\mathrm{NPP}=\frac{\left(\mathrm{M}_{2}-\mathrm{M}_{1}\right) * \mathrm{~T}}{0.5 *\left(\mathrm{~S}_{1}+\mathrm{S}_{\mathrm{m}}\right) * \mathrm{~T}^{\prime}}
$$

where: NPP - net productivity of photosynthesis, $\mathrm{g} / \mathrm{m}^{2}$ per day; $\mathrm{M}_{1}, \mathrm{M}_{2}$ - mass of plants per pcs area at the beginning and end of a certain period (development phase), g; $S_{1}, S_{2}$ leaf area in the same periods (development phases) definition, $\mathrm{cm}^{2}$; $\mathrm{T}$ - the duration of the period, days (Nichiporovich et al., 1969; Rozhkov et al., 2016).

The variability of photosynthetic productivity of soybean plants and individual phases of development was determined by the indicators of the arithmetic mean, standard deviation $\left(\mathrm{S}_{\overline{\mathrm{N}}}, \%\right)$, coefficient of variation $(\mathrm{V}, \%)$, and confidence interval of averages. Statistical data processing (correlation of average air temperature and 
precipitation with photosynthetic productivity of plants) was performed using correlation and regression analyses. Evaluation of the reliability of the obtained data in comparison with the average was checked using Student's test (t-criterion) using Excel (X16-45328-01) (Ermantraut et al., 2007).

Soil preparation and cultivation were typical for the region (Tishchenko et al., 2015). Maximum weed control, moisture accumulation and favorable conditions for the growth and development of soybean plants were envisaged. The predecessor of soybeans was spring wheat. After harvesting the predecessor, disking was carried out, then plowing to a depth of 25-27 cm. The sowing was carried out with a selection seeder SSFK-7, followed by rolling with ring-spur rollers. Two or three manual loosening operations between rows were performed during the cultivation season before closing the rows of plants. Soybeans were harvested in the phase of full ripeness of beans with a grain moisture content of 16-18\% using Sampo harvester.

\section{Results and discussion}

Weather conditions during the soybean growing season over the years of research had certain features. Taking into account the average long-term observations, soybean sowing began in the first decade of May, and harvesting was in the second decade of September. Considering this, the focus of observing the hydrothermal conditions was on the period from May to September, which determined the features of the formation of soybean crop productivity.

The growing season of soybeans in 2015 was characterized by dry conditions. There were nine abnormally warm decades, the warmest were the first and the third decades of July, with a deviation of 3.2 and $2.7^{\circ} \mathrm{C}$. The second decade of July was abnormally cool, with a deviation from the norm of $2.7^{\circ} \mathrm{C}$ (the night temperature dropped to $11.1^{\circ} \mathrm{C}$ ). The amount of precipitation was $215.9 \mathrm{~mm}$, which is $74.1 \mathrm{~mm}$ less than the long-term norm. The average daily air temperature over the period was $19.6{ }^{\circ} \mathrm{C}\left(2.5^{\circ} \mathrm{C}\right.$ higher than normal). The total of the temperature values $10^{\circ} \mathrm{C}$ during the vegetation season was $3082{ }^{\circ} \mathrm{C}$, or $377^{\circ} \mathrm{C}$ higher than normal.

The optimal conditions of the growing season developed in 2016. The amount of precipitation was $344.4 \mathrm{~mm}$, which exceeded the normal by $54.4 \mathrm{~mm}$. The average daily air temperature during the growing season was $19.6^{\circ} \mathrm{C}$; the sum of active temperatures was $3207.8^{\circ} \mathrm{C}$, which was $502.8^{\circ} \mathrm{C}$ higher than the average long-term.

The growing season of soybeans in 2017 was characterized by dry conditions with eight abnormally warm decades, with the first and the second decades of April having been the warmest (deviations from the norm of 6.8 and $7.2^{\circ} \mathrm{C}$ ). The second decade of May was abnormally cool (deviation from the norm of $4.7^{\circ} \mathrm{C}$ ). The amount of precipitation during the growing season was $163.9 \mathrm{~mm}$, which is $149.1 \mathrm{~mm}(52.4 \%)$ less than the long-term norm. The air temperature during the growing season was $18.2^{\circ} \mathrm{C}$ $\left(2.1{ }^{\circ} \mathrm{C}\right.$ more than normal) the total of active temperatures was $3176{ }^{\circ} \mathrm{C}$, or $471{ }^{\circ} \mathrm{C}$ higher than the average long-term (Table 1).

The growing season of soybeans in 2018 was less favorable; it was characterized by dry conditions with nineteen abnormally warm decades; the warmest were the first decades of May and September (deviations from the norm of 9.3 and $6.9^{\circ} \mathrm{C}$ ). The amount of precipitation during the growing season was $107.8 \mathrm{~mm}$, which is $35.9 \%$ of the normal value. Rains were few in the first decades of April and June and in the third decade of July, only $14.0 \%$. The air temperature during the growing season was 
$20.5^{\circ} \mathrm{C}$; the total of active temperatures (values above $10^{\circ} \mathrm{C}$ ) during the growing season was $3291.5^{\circ} \mathrm{C}$, which was $586.5^{\circ} \mathrm{C}$ higher than normal.

Table 1. Meteorological data for the soybean growing season in the years of research according to the meteorological station of Kharkiv Dokuchaev NAU (latitude 49.893815 ${ }^{\circ}$, longitude $\left.36.449448^{\circ}\right)$

\begin{tabular}{c|c|c|c|c|c|c|c|c|c|c|c}
\hline \multirow{3}{*}{ Months } & \multirow{3}{*}{ Decades } & \multicolumn{3}{|c|}{ Average air temperature, } & \multicolumn{3}{c}{ The amount of precipitation, mm } \\
\cline { 3 - 12 } & & $\mathbf{2 0 1 5}$ & $\mathbf{2 0 1 6}$ & $\mathbf{2 0 1 7}$ & $\mathbf{2 0 1 8}$ & $\begin{array}{c}\text { For 50 } \\
\text { years }\end{array}$ & $\mathbf{2 0 1 5}$ & $\mathbf{2 0 1 6}$ & $\mathbf{2 0 1 7}$ & $\mathbf{2 0 1 8}$ & $\begin{array}{c}\text { For 50 } \\
\text { years }\end{array}$ \\
\hline \multirow{4}{*}{ V } & 1 & 14.1 & 19.5 & 16.7 & 23.2 & 13.9 & 31.7 & 65.6 & 1.8 & 0.0 & 15.0 \\
& 2 & 16.4 & 16.0 & 11.1 & 16.7 & 15.8 & 7.8 & 19.9 & 24.9 & 15.9 & 13.0 \\
& 3 & 21.2 & 19.5 & 18.3 & 19.9 & 16.4 & 7.0 & 5.9 & 8.9 & 0.0 & 21.0 \\
& & 17.2 & 18.3 & 15.4 & 19.9 & 15.4 & 46.5 & 91.4 & 35.6 & 15.9 & 49.0 \\
\hline \multirow{4}{*}{ VI } & 1 & 22.2 & 17.2 & 19.2 & 17.9 & 18.7 & 13.6 & 0.5 & 1.2 & 2.2 & 15.0 \\
& 2 & 22.8 & 21.2 & 19.2 & 22.9 & 18.9 & 16.4 & 35.3 & 7.9 & 6.7 & 22.0 \\
& 3 & 21.7 & 25.6 & 22.9 & 24.1 & 19.9 & 74.5 & 7.5 & 9.5 & 34.6 & 22.0 \\
& & 22.2 & 21.3 & 20.4 & 21.6 & 19.2 & 104.5 & 43.3 & 18.6 & 43.5 & 59.0 \\
\hline \multirow{4}{*}{ VII } & 1 & 23.4 & 22.3 & 19.3 & 22.0 & 20.2 & 0.3 & 4.7 & 1.1 & 6.7 & 17.0 \\
& 2 & 18.2 & 25.8 & 21.5 & 22.1 & 20.9 & 23.6 & 94.8 & 15.1 & 18.5 & 29.0 \\
& 3 & 23.2 & 21.9 & 24.3 & 25.0 & 20.5 & 18.7 & 6.9 & 15.4 & 3.5 & 25.0 \\
& & 21.6 & 23.3 & 21.7 & 23.0 & 20.5 & 42.6 & 106.4 & 31.6 & 28.7 & 71.0 \\
\hline \multirow{4}{*}{ VIII } & 1 & 24.2 & 22.8 & 27.3 & 24.0 & 20.5 & 0.0 & 14.5 & 0.0 & 0.0 & 16.0 \\
& 2 & 21.0 & 20.9 & 27.3 & 25.1 & 20.1 & 0.0 & 36.1 & 0.0 & 0.0 & 21.0 \\
& 3 & 21.5 & 24.7 & 19.4 & 24.7 & 18.3 & 0.0 & 0.0 & 11.4 & 0.0 & 19.0 \\
& & 22.2 & 22.8 & 24.7 & 24.6 & 19.6 & 0.0 & 50.6 & 11.4 & 0.0 & 56.0 \\
\hline \multirow{3}{*}{ IX } & 1 & 21.8 & 19.4 & 17.8 & 23.2 & 16.3 & 3.5 & 0.0 & 25.1 & 6.8 & 17.0 \\
& 2 & 17.2 & 14.7 & 21.3 & 20.1 & 13.7 & 3.3 & 1.1 & 0.6 & 3.9 & 13.0 \\
& & 19.5 & 17.1 & 19.6 & 21.7 & 15.0 & 6.8 & 1.1 & 25.7 & 10.7 & 30.0 \\
\hline
\end{tabular}

Over the period of research, the leaf areas have been found to vary, on the average, in the phase of $\mathrm{BBCH} 13$. The value of this feature ranged from 5.6 ths. $\mathrm{m}^{2} / \mathrm{ha}$ in plants of Annushka variety, for $70 \mathrm{~cm}$ row spacing sowing and a seeding rate of 0.8 million pcs./ha, to 10.3 ths. $\mathrm{m}^{2} / \mathrm{ha}$ with the Baika variety with row sowing method and sowing rates of 1.2 million pcs./ha. In terms of the years, the smallest area of 5.1 ths. $\mathrm{m}^{2} /$ ha was formed under less favorable, arid conditions in 2018 (in plants of the Annushka variety) while the largest was under favorable conditions in 2016 amounting to11.5 ths. $\mathrm{m}^{2} / \mathrm{ha}$ (in the Baika variety with a row spacing of $15 \mathrm{~cm}$ and seeding rates of 1.2 million pcs./ha) (Table 2).

During the growth and development of soybean plants, the leaf area increased, on the average over four years, reaching the maximum in the BBCH 77 phase. In this phase, the largest surface leaf area was actually 35.0 ths. $\mathrm{m}^{2} /$ ha, observed in soybean plants Baika with a row sowing method and the maximum seeding rate in the experiment (1.2 million pcs./ha); the lowest was 26.5 ths. $\mathrm{m}^{2} /$ ha in areas of Annushka soybean variety with a row spacing of $70 \mathrm{~cm}$ and the minimum seeding rate in the experiment (0.8 million pcs/ha). As for the years, the smallest area was formed in 2018 23.8 ths. $\mathrm{m}^{2} /$ ha (in plants of the Annushka variety for row spacing of 70 sowing and 
seeding rate of 0.8 million pcs./ha) while the largest was observed in 2016, 40.5 ths. $\mathrm{m}^{2} /$ ha (in the Baika variety with $15 \mathrm{~cm}$ row spacing and seeding rates of 1.2 million pcs./ha).

Table 2. Dynamics of growth of the leaf surface area of soybean plants depending on the research factors, ths $\mathrm{m}^{2} / \mathrm{ha}$ (mean \pm sx for 2015-2018)

\begin{tabular}{|c|c|c|c|c|c|c|c|}
\hline \multirow{2}{*}{$\begin{array}{c}\text { Variety } \\
\text { (factor A) }\end{array}$} & \multirow{2}{*}{\begin{tabular}{|c|} 
Row spacing, \\
cm \\
(factor B) \\
\end{tabular}} & \multirow{2}{*}{\begin{tabular}{|c|}
$\begin{array}{c}\text { Sowing rate, } \\
\text { million pcs./ha } \\
\text { (factor } \mathrm{C} \text { ) }\end{array}$ \\
\end{tabular}} & \multicolumn{5}{|c|}{ Phases of development (classification BBCH) } \\
\hline & & & BBCH 13 & ВBCH 61 & ВBCH 67 & ВBCH 77 & ВBCH 92 \\
\hline \multirow{15}{*}{ Baika } & \multirow[t]{5}{*}{ (16) } & 0.8 & $7.3 \pm 1.09^{\text {ns }}$ & $16.2 \pm 1.75^{\mathrm{ns}}$ & $28.7 \pm 3.26^{\mathrm{ns}}$ & $32.2 \pm 3.71^{\mathrm{ns}}$ & $28.9 \pm 3.49^{\text {ns }}$ \\
\hline & & 0.9 & $8.2 \pm 1.22^{\mathrm{ns}}$ & $17.0 \pm 1.74^{\mathrm{ns}}$ & $29.5 \pm 3.11^{\mathrm{ns}}$ & $32.9 \pm 3.70^{\text {ns }}$ & $29.7 \pm 3.67^{\mathrm{ns}}$ \\
\hline & & 1.0 & $8.8 \pm 1.19^{\mathrm{ns}}$ & $17.6 \pm 1.64^{*}$ & $30.3 \pm 2.90^{*}$ & $33.7 \pm 3.31^{\mathrm{ns}}$ & $30.4 \pm 3.24^{\mathrm{ns}}$ \\
\hline & & 1.1 & $9.5 \pm 1.30^{*}$ & $18.3 \pm 1.14^{*}$ & $31.1 \pm 2.14^{*}$ & $34.2 \pm 2.53^{*}$ & $31.0 \pm 2.57^{\mathrm{ns}}$ \\
\hline & & 1.2 & $10.3 \pm 1.32^{*}$ & $19.1 \pm 1.13^{*}$ & $31.9 \pm 1.99^{*}$ & $35.0 \pm 2.49^{*}$ & $31.7 \pm 2.46^{*}$ \\
\hline & \multirow{5}{*}{45} & 0.8 & $6.9 \pm 0.77^{*}$ & $15.5 \pm 1.44^{\mathrm{ns}}$ & $27.8 \pm 2.72^{\mathrm{ns}}$ & $31.4 \pm 3.18^{\mathrm{ns}}$ & $28.0 \pm 2.97^{\text {ns }}$ \\
\hline & & 0.9 & $8.1 \pm 0.97^{\mathrm{ns}}$ & $16.2 \pm 1.30^{\mathrm{ns}}$ & $28.5 \pm 2.39^{\text {ns }}$ & $32.1 \pm 2.94^{\mathrm{ns}}$ & $28.7 \pm 2.85^{\mathrm{ns}}$ \\
\hline & & 1.0 & $8.6 \pm 1.04^{\mathrm{ns}}$ & $17.0 \pm 1.13^{*}$ & $29.2 \pm 1.92^{\mathrm{ns}}$ & $32.7 \pm 2.29^{\mathrm{ns}}$ & $29.5 \pm 2.19^{\mathrm{ns}}$ \\
\hline & & 1.1 & $9.3 \pm 0.91^{*}$ & $17.6 \pm 0.99^{*}$ & $30.1 \pm 1.84^{*}$ & $33.4 \pm 2.17^{\mathrm{ns}}$ & $30.1 \pm 2.18^{\mathrm{ns}}$ \\
\hline & & 1.2 & $10.1 \pm 0.93^{*}$ & $18.5 \pm 1.14^{*}$ & $31.0 \pm 1.94^{*}$ & $34.0 \pm 2.48^{*}$ & $30.9 \pm 2.70^{\text {ns }}$ \\
\hline & \multirow{5}{*}{70} & 0.8 & $6.5 \pm 0.73^{*}$ & $15.1 \pm 1.42^{\mathrm{ns}}$ & $27.1 \pm 2.67^{\mathrm{ns}}$ & $30.6 \pm 3.06^{\mathrm{ns}}$ & $27.5 \pm 2.99^{\text {ns }}$ \\
\hline & & 0.9 & $7.2 \pm 0.69^{*}$ & $15.8 \pm 0.93^{\text {ns }}$ & $27.8 \pm 1.57^{\mathrm{ns}}$ & $31.3 \pm 2.01^{\mathrm{ns}}$ & $28.1 \pm 2.25^{\mathrm{ns}}$ \\
\hline & & 1.0 & $8.0 \pm 0.66^{\mathrm{ns}}$ & $16.2 \pm 0.91^{\mathrm{ns}}$ & $28.6 \pm 1.55^{\mathrm{ns}}$ & $31.8 \pm 2.08^{\mathrm{ns}}$ & $28.9 \pm 1.96^{\mathrm{ns}}$ \\
\hline & & 1.1 & $8.7 \pm 0.83^{\mathrm{ns}}$ & $16.8 \pm 0.92^{*}$ & $29.4 \pm 1.52^{*}$ & $32.7 \pm 1.93^{\mathrm{ns}}$ & $29.6 \pm 1.91^{\mathrm{ns}}$ \\
\hline & & 1.2 & $9.3 \pm 0.89^{*}$ & $17.6 \pm 0.92^{*}$ & $30.2 \pm 1.34^{*}$ & $33,3 \pm 1.77^{\mathrm{ns}}$ & $30.4 \pm 1.99^{\text {ns }}$ \\
\hline \multirow{15}{*}{ Annushka } & \multirow{5}{*}{15} & 0.8 & $6.7 \pm 0.69^{*}$ & $14.2 \pm 1.15^{*}$ & $24.9 \pm 1.72^{*}$ & $28.9 \pm 2.24^{\mathrm{ns}}$ & $26.5 \pm 2.45^{\mathrm{ns}}$ \\
\hline & & 0.9 & $7.7 \pm 0.89^{\mathrm{ns}}$ & $14.8 \pm 1.19^{\mathrm{ns}}$ & $25.6 \pm 1.66^{\mathrm{ns}}$ & $29.5 \pm 2.27^{\mathrm{ns}}$ & $27.0 \pm 2.51^{\mathrm{ns}}$ \\
\hline & & 1.0 & $8.5 \pm 1.18^{\mathrm{ns}}$ & $15.5 \pm 1.20^{\mathrm{ns}}$ & $26.4 \pm 1.81^{\mathrm{ns}}$ & $30.4 \pm 2.33^{\mathrm{ns}}$ & $27.8 \pm 2.64^{\mathrm{ns}}$ \\
\hline & & 1.1 & $9.0 \pm 1.14^{\mathrm{ns}}$ & $16.4 \pm 0.99^{\mathrm{ns}}$ & $27.7 \pm 1.66^{\mathrm{ns}}$ & $31.6 \pm 2.37^{\mathrm{ns}}$ & $28.7 \pm 2.79^{\text {ns }}$ \\
\hline & & 1.2 & $9.9 \pm 1.25^{*}$ & $17.3 \pm 1.29^{*}$ & $28.7 \pm 2.14^{\mathrm{ns}}$ & $32.6 \pm 2.88^{\mathrm{ns}}$ & $29.5 \pm 2.94^{\mathrm{ns}}$ \\
\hline & \multirow{5}{*}{45} & 0.8 & $5.9 \pm 0.42^{*}$ & $12.7 \pm 0.60^{*}$ & $23.2 \pm 1.28^{*}$ & $27.5 \pm 1.95^{*}$ & $25.0 \pm 1.98^{*}$ \\
\hline & & 0.9 & $6.8 \pm 0.54^{*}$ & $13.3 \pm 0.69^{*}$ & $23.8 \pm 1.44^{*}$ & $28.2 \pm 2.14^{*}$ & $25.6 \pm 2.15^{*}$ \\
\hline & & 1.0 & $7.6 \pm 0.71^{\mathrm{ns}}$ & $13.9 \pm 0.77^{*}$ & $24.5 \pm 1.45^{*}$ & $28.9 \pm 2.21^{\mathrm{ns}}$ & $26.2 \pm 2.29^{\mathrm{ns}}$ \\
\hline & & 1.1 & $8.5 \pm 0.71^{\mathrm{ns}}$ & $14.8 \pm 0.87^{\mathrm{ns}}$ & $25.7 \pm 1.33^{*}$ & $29.9 \pm 2.03^{\mathrm{ns}}$ & $27.2 \pm 2.24^{\mathrm{ns}}$ \\
\hline & & 1.2 & $9.3 \pm 0.78^{*}$ & $15.6 \pm 1.08^{\mathrm{ns}}$ & $26.7 \pm 1.42^{\mathrm{ns}}$ & $30.7 \pm 2.04^{\mathrm{ns}}$ & $28.2 \pm 2.21^{\mathrm{ns}}$ \\
\hline & \multirow{5}{*}{70} & 0.8 & $5.6 \pm 0.49^{*}$ & $11.9 \pm 0.39^{*}$ & $22.1 \pm 0.90^{*}$ & $26.5 \pm 1.55^{*}$ & $24.1 \pm 1.67^{*}$ \\
\hline & & 0.9 & $6.4 \pm 0.46^{*}$ & $12.6 \pm 0.38^{*}$ & $22.7 \pm 0.78^{*}$ & $27.0 \pm 1.47^{*}$ & $24.6 \pm 1.59^{*}$ \\
\hline & & 1.0 & $7.1 \pm 0.53^{*}$ & $13.1 \pm 0.52^{*}$ & $23.4 \pm 0.92^{*}$ & $27.8 \pm 1.59^{*}$ & $25.3 \pm 1.65^{*}$ \\
\hline & & 1.1 & $8.0 \pm 0.72^{\mathrm{ns}}$ & $14.1 \pm 0.48^{*}$ & $24.2 \pm 0.94^{*}$ & $28.5 \pm 1.42^{*}$ & $26.1 \pm 1.57^{*}$ \\
\hline & & 1.2 & $8.7 \pm 0.81^{\mathrm{ns}}$ & $14.9 \pm 0.73^{*}$ & $25.3 \pm 1.20^{*}$ & $29.3 \pm 1.64^{\mathrm{ns}}$ & $26.8 \pm 1.85^{\mathrm{ns}}$ \\
\hline \multicolumn{3}{|c|}{ Average } & 7.9 & 15.2 & 26.5 & 30.4 & 27.5 \\
\hline \multicolumn{3}{|c|}{$\mathrm{V}, \%$} & 12.8 & 7.5 & 7.9 & 9.1 & 10.4 \\
\hline \multicolumn{3}{|c|}{$S_{x, \%}$} & 4.5 & 2.7 & 2.8 & 3.2 & 3.7 \\
\hline
\end{tabular}

\pm- confidence interval; $*-t_{\text {fact. }} \geq \mathrm{t}_{\text {theor. }}$ (essential for the level 0.05$) ; n s-t_{\text {fact. }}<t_{\text {theor. }}$ (insignificant for the level 0.05 )

During the BBCH 92 phase, soybean plants began to lose their lower tier leaves and fall off. This has reduced the leaf surface. In this phase, the smallest leaf surface area 24.1 ths $\mathrm{m}^{2} / \mathrm{ha}$ - was in soybean plants of the variety Annushka with a row spacing of 70 $\mathrm{cm}$ and a seed sowing rate of 0.8 million pcs./ha. The largest was -31.7 ths. $\mathrm{m}^{2} / \mathrm{ha}-$ in the variety Baika with a row method of sowing and a seeding rate of 1.2 million pcs./ha. By years, the smallest area was formed in $2018-21.4$ ths. $\mathrm{m}^{2} / \mathrm{ha}$ (in varieties Annushka for sowing with a row spacing of $70 \mathrm{~cm}$ and a seeding rate of 0.8 million pcs./ha), and 
the largest was in $2016-37.5$ ths. $\mathrm{m}^{2} / \mathrm{ha}$ (in the variety Baika with a row spacing of $15 \mathrm{~cm}$ and seeding rates of 1.2 million pcs./ha).

The formation of the leaf surface area is a prerequisite for obtaining maximum crop yields. Both in our observations and according to the results of many studies in the Forest Steppe of Ukraine, it was proved that the optimal leaf surface area for soybeans was 40-50 ths. $\mathrm{m}^{2} /$ ha (Babych et al., 2003; Dzhemesiuk et al., 2015; Nichiporovich et al., 1969; Rahman et al., 2011), and in the Polissya zone, depending on sowing dates and sowing rates, fluctuated within $44-60$ ths. $\mathrm{m}^{2} /$ ha (Didora et al., 2013).

On the average over the period of four years of research, the variety-related difference has been observed. It included the following: in the BBCH 13 phase, a super early (0000) Annushka variety formed a leaf area by 0.7 ths. $\mathrm{m}^{2} /$ ha smaller than the early (000) Baika variety. The maximum difference between the varieties in leaf surface area, 4.4 ths $\mathrm{m}^{2} /$ ha, was observed in the period $\mathrm{BBCH} 61-\mathrm{BBCH} 67$, which was confirmed by studies of other researchers (Mikheev, 2014; Ogurtsov, 2008). Later, the difference gradually reduced, namely, in the phase of $\mathrm{BBCH} 77$ it was 3.6 ths. $\mathrm{m}^{2} / \mathrm{ha}$, and in the phase of $\mathrm{BBCH}-92-3.0$ ths. $\mathrm{m}^{2} /$ ha.

In row crops, the leaf surface area of soybean plants was larger than in broad-row crops, as shown also in other studies (Cox and Cherney, 2011; Mikheev, 2012; Shepilova and Petrenko, 2017). In the BBCH 13 phase, the difference was 0.5 and 1.0 ths. $\mathrm{m}^{2} /$ ha at row spacing of 45 and $70 \mathrm{~cm}$, respectively. During the period $\mathrm{BBCH}$ $61-\mathrm{BBCH} 67$ the difference increased to 1.4 and 2.4 ths. $\mathrm{m}^{2} / \mathrm{ha}$, as per the sowing methods. In the phase of $\mathrm{BBCH} 77$, at the maximum leaf area, the difference was 1.2 and 2.2 ths. $\mathrm{m}^{2} /$ ha.

Increasing the seeding rate from 0.8 to 1.2 million $\mathrm{pcs} / \mathrm{ha}$ contributed to an increase in leaf area. In the BBCH 13 phase, the difference amounted to $3.1 \mathrm{ths} . \mathrm{m}^{2} / \mathrm{ha}$, in the period $\mathrm{BBCH} 61-\mathrm{BBCH} 67$, the difference increased to 3.4 ths. $\mathrm{m}^{2} /$ ha. Over the time, the difference gradually decreased, and in the phase of BBCH 92 seeds it was -2.9 ths. $\mathrm{m}^{2} / \mathrm{ha}$, depending upon the seeding rates. The research results are consistent with those described by other authors (Ogurtsov, 2008). However, certain studies demonstrate that crop thickening caused no changes in leaf area (Kazachenko, 2010; Raniele et al., 2016), and in sometimes even resulted in its reduction (Shepilova and Petrenko, 2017).

Crop productivity was determined by photosynthetic potential (PP). It characterizes the dynamic changes in leaf area over the vegetation period and demonstrates the typical features of plant growth and development including the formation of the soybean leaf surface depending on the conditions that influence its progress (Baranov and Ugo Toro Korrea, 2006).

Our observation shows that, on the average over the years of research, the PP index values varied in the interphase period of $\mathrm{BBCH}$ 13-61. The values ranged from 0.045 million $\mathrm{m}^{2} /$ ha per day in plants of Annushka variety with $70 \mathrm{~cm}$ row spacing sowing and seeding rate of 0.8 million pcs./ha to 0.149 million $\mathrm{m}^{2} / \mathrm{ha}$ per day in soybean plants of Baika variety, row sowing method, and sowing rates 1.2 million pcs./ha (Table 3). Across years, the lowest PP formed under less favorable, dry conditions in 2017, with 0.040 million $\mathrm{m}^{2}$ /ha per day (in plants of Annushka variety, $70 \mathrm{~cm}$ row spacing, seeding rate 0.8 million pcs./ha while the highest value, in more favorable conditions of 2016 with more precipitation, it was 0.195 million $\mathrm{m}^{2} / \mathrm{ha}$ per day (in the Baika variety, $15 \mathrm{~cm}$ row spacing, seeding rates 1.0 million pcs./ha).

In the process of growth and development of soybean plants, PP increased, reaching the maximum values in the interphase period $\mathrm{BBCH}$ 77-92. The largest PP, 
2.458 million $\mathrm{m}^{2} /$ ha per day, was observed in areas of Baika variety, row sowing method, seeding rate 0.9 million pcs./ha; the lowest was 1.510 million $\mathrm{m}^{2} /$ ha per day in areas of Annushka variety, $70 \mathrm{~cm}$ row spacing, seeding rate 0.8 million pcs./ha. In the observed years, the smallest area was formed in 2018, namely, 1.249 million $\mathrm{m}^{2} / \mathrm{ha}$ per day (Annushka variety, row spacing $70 \mathrm{~cm}$, seeding rate 0.9 million pcs./ha) while the highest, in 2016, was 3.239 million $\mathrm{m}^{2} /$ ha per day (Baika variety, $15 \mathrm{~cm}$ row spacing, seeding rates 0.9 million pcs./ha).

Table 3. Dynamics of soybean plants photosynthetic potential (PP) growth depending on the factors studied, million $\mathrm{m}^{2} / \mathrm{ha}$ per day (mean \pm sx for 2015-2018)

\begin{tabular}{|c|c|c|c|c|c|c|}
\hline \multirow{2}{*}{$\begin{array}{c}\text { Variety } \\
\text { (factor A) }\end{array}$} & \multirow{2}{*}{$\begin{array}{c}\text { Row spacing, } \\
\text { cm } \\
\text { (factor B) }\end{array}$} & \multirow{2}{*}{$\begin{array}{c}\text { Sowing rate, } \\
\text { million pcs./ha } \\
\text { (factor } \mathrm{C})\end{array}$} & \multicolumn{4}{|c|}{ Interphase periods of growth and development of soybean plants } \\
\hline & & & $\begin{array}{c}\text { ВВСH } \\
13-61 \\
\end{array}$ & $\begin{array}{c}\text { ВВСН } \\
61-67 \\
\end{array}$ & $\begin{array}{c}\text { ВBCH } \\
67-77 \\
\end{array}$ & $\begin{array}{c}\text { ВВСН } \\
77-92 \\
\end{array}$ \\
\hline \multirow{15}{*}{ Baika } & \multirow{5}{*}{15} & 0.8 & $0.142 \pm 0.065^{\mathrm{ns}}$ & $1.102 \pm 0.36^{\mathrm{ns}}$ & $2.030 \pm 0.312^{\mathrm{ns}}$ & $2.414 \pm 0.356^{*}$ \\
\hline & & 0.9 & $0.142 \pm 0.059^{\mathrm{ns}}$ & $1.114 \pm 0.32^{\mathrm{ns}}$ & $2.064 \pm 0.302 *$ & $2.458 \pm 0.346^{*}$ \\
\hline & & 1.0 & $0.146 \pm 0.064^{\mathrm{ns}}$ & $1.134 \pm 0.33^{\mathrm{ns}}$ & $2.072 \pm 0.287 *$ & $2.439 \pm 0.326^{*}$ \\
\hline & & 1.1 & $0.139 \pm 0.050^{\mathrm{ns}}$ & $1.108 \pm 0.25^{\mathrm{ns}}$ & $2.033 \pm 0.236^{*}$ & $2.400 \pm 0.274 *$ \\
\hline & & 1.2 & $0.149 \pm 0.052^{*}$ & $1.155 \pm 0.25^{*}$ & $2.080 \pm 0.230 *$ & $2.430 \pm 0.258^{*}$ \\
\hline & \multirow{5}{*}{45} & 0.8 & $0.124 \pm 0.054^{\mathrm{ns}}$ & $1.048 \pm 0.30^{\mathrm{ns}}$ & $1.944 \pm 0.277^{\mathrm{ns}}$ & $2.315 \pm 0.316^{\mathrm{ns}}$ \\
\hline & & 0.9 & $0.134 \pm 0.056^{\mathrm{ns}}$ & $1.058 \pm 0.28^{\mathrm{ns}}$ & $1.943 \pm 0.256^{\mathrm{ns}}$ & $2.320 \pm 0.293^{\mathrm{ns}}$ \\
\hline & & 1.0 & $0.127 \pm 0.053^{\mathrm{ns}}$ & $1.063 \pm 0.25^{\mathrm{ns}}$ & $1.941 \pm 0.229^{\mathrm{ns}}$ & $2.289 \pm 0.263^{\mathrm{ns}}$ \\
\hline & & 1.1 & $0.132 \pm 0.053^{\mathrm{ns}}$ & $1.068 \pm 0.24^{\mathrm{ns}}$ & $1.942 \pm 0.221^{\mathrm{ns}}$ & $2.297 \pm 0.254^{\mathrm{ns}}$ \\
\hline & & 1.2 & $0.130 \pm 0.048^{\mathrm{ns}}$ & $1.111 \pm 0.25^{\mathrm{ns}}$ & $2.014 \pm 0.236^{*}$ & $2.356 \pm 0.261^{*}$ \\
\hline & \multirow{5}{*}{70} & 0.8 & $0.120 \pm 0.053^{\mathrm{ns}}$ & $1.006 \pm 0.30^{\mathrm{ns}}$ & $1.856 \pm 0.271^{\mathrm{ns}}$ & $2.221 \pm 0.310^{\mathrm{ns}}$ \\
\hline & & 0.9 & $0.124 \pm 0.047^{\mathrm{ns}}$ & $1.008 \pm 0.22^{\mathrm{ns}}$ & $1.844 \pm 0.208^{\mathrm{ns}}$ & $2.183 \pm 0.236^{\mathrm{ns}}$ \\
\hline & & 1.0 & $0.121 \pm 0.041^{\mathrm{ns}}$ & $1.001 \pm 0.21^{\mathrm{ns}}$ & $1.823 \pm 0.204^{\mathrm{ns}}$ & $2.162 \pm 0.237^{\mathrm{ns}}$ \\
\hline & & 1.1 & $0.125 \pm 0.050^{\mathrm{ns}}$ & $1.030 \pm 0.22^{\mathrm{ns}}$ & $1.870 \pm 0.208^{\mathrm{ns}}$ & $2.193 \pm 0.234^{\mathrm{ns}}$ \\
\hline & & 1.2 & $0.121 \pm 0.043^{\mathrm{ns}}$ & $1.033 \pm 0.20^{\mathrm{ns}}$ & $1.861 \pm 0.201^{\mathrm{ns}}$ & $2.190 \pm 0.225^{\mathrm{ns}}$ \\
\hline \multirow{15}{*}{ Annushka } & \multirow{5}{*}{15} & 0.8 & $0.063 \pm 0.017^{*}$ & $0.765 \pm 0.15^{\mathrm{ns}}$ & $1.501 \pm 0.137^{\mathrm{ns}}$ & $1.760 \pm 0.196^{\mathrm{ns}}$ \\
\hline & & 0.9 & $0.060 \pm 0.018^{*}$ & $0.765 \pm 0.13^{*}$ & $1.492 \pm 0.123^{\mathrm{ns}}$ & $1.727 \pm 0.182^{\mathrm{ns}}$ \\
\hline & & 1.0 & $0.061 \pm 0.019^{*}$ & $0.785 \pm 0.16^{\mathrm{ns}}$ & $1.527 \pm 0.142^{\mathrm{ns}}$ & $1.769 \pm 0.204^{\mathrm{ns}}$ \\
\hline & & 1.1 & $0.064 \pm 0.018^{*}$ & $0.811 \pm 0.14^{\mathrm{ns}}$ & $1.571 \pm 0.136^{\mathrm{ns}}$ & $1.819 \pm 0.196^{\mathrm{ns}}$ \\
\hline & & 1.2 & $0.059 \pm 0.023^{*}$ & $0.821 \pm 0.17^{\mathrm{ns}}$ & $1.590 \pm 0.147^{\mathrm{ns}}$ & $1.825 \pm 0.208^{\mathrm{ns}}$ \\
\hline & \multirow{5}{*}{45} & 0.8 & $0.056 \pm 0.014^{*}$ & $0.688 \pm 0.10^{*}$ & $1.384 \pm 0.106^{*}$ & $1.604 \pm 0.162 *$ \\
\hline & & 0.9 & $0.053 \pm 0.019^{*}$ & $0.704 \pm 0.11^{*}$ & $1.395 \pm 0.105 *$ & $1.620 \pm 0.165^{*}$ \\
\hline & & 1.0 & $0.057 \pm 0.018^{*}$ & $0.724 \pm 0.12 *$ & $1.424 \pm 0.117 *$ & $1.654 \pm 0.177 *$ \\
\hline & & 1.1 & $0.050 \pm 0.021^{*}$ & $0.733 \pm 0.11^{*}$ & $1.434 \pm 0.104 *$ & $1.648 \pm 0.158^{*}$ \\
\hline & & 1.2 & $0.054 \pm 0.021^{*}$ & $0.760 \pm 0.12 *$ & $1.482 \pm 0.111^{*}$ & $1.694 \pm 0.168^{*}$ \\
\hline & \multirow{5}{*}{70} & 0.8 & $0.045 \pm 0.015^{*}$ & $0.645 \pm 0.08^{*}$ & $1.297 \pm 0.086^{*}$ & $1.510 \pm 0.140^{*}$ \\
\hline & & 0.9 & $0.048 \pm 0.014^{*}$ & $0.660 \pm 0.07 *$ & $1.314 \pm 0.088^{*}$ & $1.527 \pm 0.139 *$ \\
\hline & & 1.0 & $0.051 \pm 0.015^{*}$ & $0.667 \pm 0.09 *$ & $1.319 \pm 0.090 *$ & $1.518 \pm 0.138^{*}$ \\
\hline & & 1.1 & $0.047 \pm 0.019^{*}$ & $0.686 \pm 0.08^{*}$ & $1.350 \pm 0.083^{*}$ & $1.546 \pm 0.134^{*}$ \\
\hline & & 1.2 & $0.051 \pm 0.020^{*}$ & $0.718 \pm 0.11 *$ & $1.403 \pm 0.109^{*}$ & $1.607 \pm 0.165^{*}$ \\
\hline \multirow{2}{*}{\multicolumn{3}{|c|}{ Average }} & 0.093 & 0.899 & 1.693 & 1.983 \\
\hline & & & 16.9 & 12.7 & 16.1 & 17.3 \\
\hline \multicolumn{3}{|c|}{$S_{x, \%}$} & 5.3 & 6.4 & 4.7 & 4.9 \\
\hline
\end{tabular}

\pm- confidence interval; $*-\mathrm{t}_{\text {fact. }} \geq \mathrm{t}_{\text {theor. }}$ (essential for the level 0.05$)$; $\mathrm{ns}-\mathrm{t}_{\text {fact. }}<\mathrm{t}_{\text {theor. }}$ (insignificant for the level 0.05 )

On the average over four years of research, the variety-related difference was observed. In the interphase period $\mathrm{BBCH} 13-61$, the super early (0000) variety 
Annushka formed PP by 0.077 million $\mathrm{m}^{2} /$ ha lower than the early (000) Baika variety. Over time, the difference gradually increased reaching the maximum over the period BBCH 77-92, namely, 0.656 millionm $^{2} /$ ha per day.

In row crops, soybean plant PP was higher than in wide-row crops, observed also by other authors (Mikheev, 2014; Tolmachev and Sinegovskaja, 2009). In our studies, during the interphase period of $\mathrm{BBCH} 13-61$, the difference was 0.011 and 0.017 million $\mathrm{m}^{2} /$ ha per day at rows of 45 and $70 \mathrm{~cm}$, respectively. Over time, the difference gradually increased reaching the maximum over the period of $\mathrm{BBCH} 77-92$, with the difference of 0.124 and 0.238 million $\mathrm{m}^{2} /$ ha per day, respectively, for rows $45 \mathrm{~cm}$ and $70 \mathrm{~cm}$.

The increase in seed sowing rate from 0.8 to 1.2 million pcs./ha caused the increase in PP. Over the period BBCH 13-61 the difference reached 0.002 million $\mathrm{m}^{2} /$ ha per day, over the period of $\mathrm{BBCH}$ 61-67 the difference increased up to 0.057 million $\mathrm{m}^{2} / \mathrm{ha}$ per day, and during the period of $\mathrm{BBCH} 67-77$, it amounted to 0.069 million $\mathrm{m}^{2} / \mathrm{ha}$ per day. After that, the difference gradually decreased, and during the period of BBCH 7792 the difference was up to 0.046 million $\mathrm{m}^{2} /$ ha per day.

The relevant factor is not only the area of leaves, but also the period of its active operation. The crops are deemed to be of sufficient productive performance provided their PP is 2 million $\mathrm{m}^{2} /$ ha per day for every 100 days of vegetation (Nichiporovich et al., 1969; Tretjakov et al., 2003), which value was actually observed in our studies.

An important feature of the plants' potential for crop formation is the net productivity of photosynthesis (NPP) (Sidorovich, 2002). It reflects the productivity of the crop per $1 \mathrm{~m}^{2}$ of leaf area during the day. In contrast to the overall productivity of photosynthesis, NPP does not contain the organic matter consumed by plants for respiration, only that which accumulates per day. Thus, the NPP reflects the actual opportunities of agrobiocenosis for the synthesis of organic matter in a more comprehensive way than the area of the leaves. It is one of the most important parameters, and the yield level correlates with it (Caulfield and Bunce, 1988). Direct yield relationship between the maximum values of NPP and seed yield is, however, not always observed (Ogurtsov, 2008). The net productivity of photosynthesis depends on both the biological characteristics of the plant and the environmental factors including solar radiation, air temperature, soil moisture, mineral nutrition, and others (Babych et al., 2003).

In contrast to the formation of the assimilation surface of the leaves, the dynamics of soybean NPP during the growing season develops differently. From BBCH 13 to $\mathrm{BBCH}$ 61 it increases, acquires an absolute maximum, and in the period $\mathrm{BBCH}$ 61-67 decreases; during the period of $\mathrm{BBCH} 67-77$ it is growing again and reaches the second maximum, although compared to the first increase in NPP, the second is significantly lower. Next, the NPP is again reduced and the formation of NPP demonstrates a sinusoidal pattern.

On the average over the years of research, in the interphase period $\mathrm{BBCH} 13-61$, NPP indexes were found to vary. The value of this indicator ranged from $9.8 \mathrm{~g} / \mathrm{m}^{2}$ per day in Annushka varieties for $70 \mathrm{~cm}$ row spacing sowing and a seeding rate of 0.8 million pcs./ha to $12.4 \mathrm{~g} / \mathrm{m}^{2}$ per day in soybean plants of Baika variety with row method sowing, sowing rates 1.0 million pcs./ha. Over the years, the lowest NPP was formed in 2018 under less favorable, dry conditions, which was $8.2 \mathrm{~g} / \mathrm{m}^{2}$ per day (in plants of the Annushka variety, $45 \mathrm{~cm}$ row spacing, seeding rate 0.8 million pcs./ha), 
while the highest was in more favorable, wet conditions of $2016-17.3 \mathrm{~g} / \mathrm{m}^{2}$ per day (Baika variety, $15 \mathrm{~cm}$ row spacing, seeding rates 1.0 million pcs./ha) (Table 4).

During BBCH 61-67, the NPP decreased almost 1.5-fold, although the assimilation surface area almost doubled during this period. In the interphase period BBCH $61-67$, the highest NPP of $7.8 \mathrm{~g} / \mathrm{m}^{2}$ per day was observed in areas of the Baika variety, row sowing method, seeding rate 1.0 million pcs./ha, while the lowest was $6.1 \mathrm{~g} / \mathrm{m}^{2}$ per day in areas of Annushka variety, $70 \mathrm{~cm}$ row spacing and a seeding rate 0.8 million pcs./ha.

The highest NPP of $8.1 \mathrm{~g} / \mathrm{m}^{2}$ per day was observed during the interphase period BBCH 67-77 in areas of the Baika variety, row sowing method, seeding rate 1.0 million pcs./ha while the lowest was $6.7 \mathrm{~g} / \mathrm{m}^{2}$ per day in areas of Annushka variety, $70 \mathrm{~cm}$ row spacing, seeding rate 0.8 million pcs./ha.

Table 4. The dynamics of growth of net photosynthetic performance (NPP) of soybean plants depending on the factors studied, $\mathrm{g} / \mathrm{m} 2$ per day (mean \pm sx for 2015-2018)

\begin{tabular}{|c|c|c|c|c|c|c|}
\hline \multirow{2}{*}{$\begin{array}{c}\text { Variety } \\
\text { (factor A) }\end{array}$} & \multirow{2}{*}{$\begin{array}{c}\text { Row spacing, } \\
\text { cm } \\
\text { (factor B) }\end{array}$} & \multirow{2}{*}{$\begin{array}{l}\text { Sowing rate, } \\
\text { million pcs./ha } \\
\text { (factor } \mathrm{C})\end{array}$} & \multicolumn{4}{|c|}{ Interphase periods of growth and development of soybean plants } \\
\hline & & & $\begin{array}{c}\text { ВBCH } \\
13-61 \\
\end{array}$ & $\begin{array}{c}\text { BBCH } \\
61-67 \\
\end{array}$ & $\begin{array}{c}\text { BBCH } \\
67-77 \\
\end{array}$ & $\begin{array}{c}\text { ВBCH } \\
77-92 \\
\end{array}$ \\
\hline \multirow{15}{*}{ Baika } & \multirow{5}{*}{15} & 0.8 & $12.1 \pm 1.10^{\mathrm{ns}}$ & $7.4 \pm 0.63^{\mathrm{ns}}$ & $7.6 \pm 0.34^{\mathrm{ns}}$ & $3.9 \pm 0.39^{\text {ns }}$ \\
\hline & & 0.9 & $12.2 \pm 1.11^{\mathrm{ns}}$ & $7.5 \pm 0.67^{\mathrm{ns}}$ & $7.8 \pm 0.39^{\mathrm{ns}}$ & $4.1 \pm 0.41^{\mathrm{ns}}$ \\
\hline & & 1.0 & $12.4 \pm 1.16^{\mathrm{ns}}$ & $7.8 \pm 0.75^{\mathrm{ns}}$ & $8.1 \pm 0.48^{*}$ & $4.3 \pm 0.50^{*}$ \\
\hline & & 1.1 & $12.3 \pm 1.07^{\mathrm{ns}}$ & $7.7 \pm 0.62^{\text {ns }}$ & $8.0 \pm 0.32 *$ & $4.2 \pm 0.36^{*}$ \\
\hline & & 1.2 & $12.3 \pm 0.98^{\mathrm{ns}}$ & $7.6 \pm 0.56^{\mathrm{ns}}$ & $7.9 \pm 0.28 *$ & $4.2 \pm 0.31^{*}$ \\
\hline & \multirow{5}{*}{45} & 0.8 & $11.6 \pm 1.17^{\mathrm{ns}}$ & $7.2 \pm 0.67^{\mathrm{ns}}$ & $7.5 \pm 0.36^{\mathrm{ns}}$ & $3.8 \pm 0.38^{\mathrm{ns}}$ \\
\hline & & 0.9 & $11.8 \pm 1.18^{\mathrm{ns}}$ & $7.3 \pm 0.67^{\mathrm{ns}}$ & $7.7 \pm 0.39^{\mathrm{ns}}$ & $4.0 \pm 0.41^{\mathrm{ns}}$ \\
\hline & & 1.0 & $11.8 \pm 1.16^{\mathrm{ns}}$ & $7.4 \pm 0.63^{\mathrm{ns}}$ & $7.8 \pm 0.35^{\mathrm{ns}}$ & $4.0 \pm 0.38^{\mathrm{ns}}$ \\
\hline & & 1.1 & $11.8 \pm 1.06^{\mathrm{ns}}$ & $7.5 \pm 0.58^{\mathrm{ns}}$ & $7.8 \pm 0.30^{*}$ & $4.0 \pm 0.34^{\mathrm{ns}}$ \\
\hline & & 1.2 & $11.8 \pm 1.06^{\mathrm{ns}}$ & $7.4 \pm 0.58^{\mathrm{ns}}$ & $7.7 \pm 0.30^{\text {ns }}$ & $3.9 \pm 0.32^{\mathrm{ns}}$ \\
\hline & \multirow{5}{*}{70} & 0.8 & $11.1 \pm 1.25^{\mathrm{ns}}$ & $6.8 \pm 0.72^{\mathrm{ns}}$ & $7.1 \pm 0.48^{\mathrm{ns}}$ & $3.5 \pm 0.42^{\mathrm{ns}}$ \\
\hline & & 0.9 & $11.3 \pm 1.18^{\mathrm{ns}}$ & $7.0 \pm 0.65^{\mathrm{ns}}$ & $7.4 \pm 0.38^{\mathrm{ns}}$ & $3.7 \pm 0.37^{\mathrm{ns}}$ \\
\hline & & 1.0 & $11.4 \pm 1.13^{\mathrm{ns}}$ & $7.0 \pm 0.63^{\mathrm{ns}}$ & $7.3 \pm 0.37^{\mathrm{ns}}$ & $3.7 \pm 0.34^{\mathrm{ns}}$ \\
\hline & & 1.1 & $11.4 \pm 1.07^{\mathrm{ns}}$ & $7.0 \pm 0.61^{\mathrm{ns}}$ & $7.3 \pm 0.38^{\mathrm{ns}}$ & $3.7 \pm 0.33^{\mathrm{ns}}$ \\
\hline & & 1.2 & $11.1 \pm 1.06^{\mathrm{ns}}$ & $6.8 \pm 0.63^{\mathrm{ns}}$ & $7.1 \pm 0.40^{\mathrm{ns}}$ & $3.5 \pm 0.34^{\mathrm{ns}}$ \\
\hline \multirow{15}{*}{ Annushka } & \multirow{5}{*}{15} & 0.8 & $10.5 \pm 0.48^{\mathrm{ns}}$ & $6.7 \pm 0.35^{\mathrm{ns}}$ & $7.2 \pm 0.17^{\mathrm{ns}}$ & $3.6 \pm 0.22^{\mathrm{ns}}$ \\
\hline & & 0.9 & $10.7 \pm 0.54^{\mathrm{ns}}$ & $6.8 \pm 0.37^{\mathrm{ns}}$ & $7.4 \pm 0.17^{\mathrm{ns}}$ & $3.7 \pm 0.23^{\mathrm{ns}}$ \\
\hline & & 1.0 & $10.8 \pm 0.50^{\mathrm{ns}}$ & $6.9 \pm 0.37^{\mathrm{ns}}$ & $7.5 \pm 0.17^{\mathrm{ns}}$ & $3.8 \pm 0.23^{\mathrm{ns}}$ \\
\hline & & 1.1 & $11.2 \pm 0.48^{\mathrm{ns}}$ & $7.1 \pm 0.38^{\mathrm{ns}}$ & $7.6 \pm 0.17^{\mathrm{ns}}$ & $3.9 \pm 0.23^{\mathrm{ns}}$ \\
\hline & & 1.2 & $11.4 \pm 0.42^{\mathrm{ns}}$ & $7.3 \pm 0.37^{\mathrm{ns}}$ & $7.7 \pm 0.17 *$ & $4.0 \pm 0.23^{\mathrm{ns}}$ \\
\hline & \multirow{5}{*}{45} & 0.8 & $10.3 \pm 0.57^{\mathrm{ns}}$ & $6.6 \pm 0.30^{\mathrm{ns}}$ & $7.1 \pm 0.17 *$ & $3.4 \pm 0.19^{*}$ \\
\hline & & 0.9 & $10.4 \pm 0.47^{\mathrm{ns}}$ & $6.7 \pm 0.32^{\mathrm{ns}}$ & $7.2 \pm 0.17^{\mathrm{ns}}$ & $3.5 \pm 0.20^{\mathrm{ns}}$ \\
\hline & & 1.0 & $10.7 \pm 0.53^{\mathrm{ns}}$ & $6.9 \pm 0.30^{\mathrm{ns}}$ & $7.3 \pm 0.16^{\mathrm{ns}}$ & $3.6 \pm 0.21^{\mathrm{ns}}$ \\
\hline & & 1.1 & $10.9 \pm 0.58^{\mathrm{ns}}$ & $7.0 \pm 0.32^{\mathrm{ns}}$ & $7.5 \pm 0.19^{\mathrm{ns}}$ & $3.7 \pm 0.22^{\mathrm{ns}}$ \\
\hline & & 1.2 & $10.8 \pm 0.41^{\mathrm{ns}}$ & $7.0 \pm 0.24^{\mathrm{ns}}$ & $7.5 \pm 0.11^{\mathrm{ns}}$ & $3.7 \pm 0.13^{\text {ns }}$ \\
\hline & \multirow{5}{*}{70} & 0.8 & $9.8 \pm 0.34^{*}$ & $6.1 \pm 0.22 *$ & $6.7 \pm 0.17 *$ & $3.2 \pm 0.17^{*}$ \\
\hline & & 0.9 & $10.0 \pm 0.46^{*}$ & $6.2 \pm 0.20^{*}$ & $6.8 \pm 0.17 *$ & $3.3 \pm 0.16^{*}$ \\
\hline & & 1.0 & $10.7 \pm 0.48^{\mathrm{ns}}$ & $6.6 \pm 0.20^{\mathrm{ns}}$ & $7.1 \pm 0.13^{*}$ & $3.5 \pm 0.19^{\text {ns }}$ \\
\hline & & 1.1 & $10.3 \pm 0.29 *$ & $6.5 \pm 0.14^{*}$ & $6.9 \pm 0.15^{*}$ & $3.4 \pm 0.14^{*}$ \\
\hline & & 1.2 & $10.3 \pm 0.29 *$ & $6.4 \pm 0.11^{*}$ & $6.8 \pm 0.13^{*}$ & $3.3 \pm 0.12^{*}$ \\
\hline \multicolumn{3}{|c|}{ Mean } & 11.2 & 7.0 & 7.4 & 3.7 \\
\hline \multicolumn{3}{|c|}{$\mathrm{V}, \%$} & 17.1 & 16.7 & 9.1 & 18.2 \\
\hline \multicolumn{3}{|c|}{$S_{x, \%}$} & 3.2 & 3.2 & 1.7 & 3.7 \\
\hline
\end{tabular}

\pm- confidence interval; $*-t_{\text {fact. }} \geq \mathrm{t}_{\text {theor. }}$ (essential for the level 0.05 ); $n s-t_{\text {fact. }}<t_{\text {theor. }}$ (insignificant for the level 0.05 ) 
In the course of further growth and development of soybean plants, NPP decreased, reaching its minimum in the interphase period $\mathrm{BBCH}$ 77-92. In particular, the highest NPP over this period of $4.3 \mathrm{~g} / \mathrm{m}^{2}$ per day was observed in areas of the variety Baika, row sowing method, seeding rate 1.0 million pcs./ha. The lowest one was $3.2 \mathrm{~g} / \mathrm{m}^{2}$ per day in areas of Annushka variety, row spacing $70 \mathrm{~cm}$, seeding rate 0.8 million pcs./ha. As to years, the lowest, $2.5 \mathrm{~g} / \mathrm{m}^{2}$ per day, was observed in 2018, plants of Annushka variety, $70 \mathrm{~cm}$ row spacing sowing, seeding rate 0.8 million pcs./ha, while the highest of $6.5 \mathrm{~g} / \mathrm{m}^{2}$ per day was recorded in 2016 , with the variety Baika, $15 \mathrm{~cm}$ row spacing, seeding rates of 1.0 million pcs./ha.

On the mean over four years of research, a variety-related difference was observed. These features included the following: in the interphase period BBCH 13-61, the super early (0000) Annushka variety formed a NPP of $1.187 \mathrm{~g} / \mathrm{m}^{2}$ per day less compared to the early (000) Baika variety. Over time, the difference gradually decreased, reaching its minimum in the period of BBCH 77-92, when it was $0.322 \mathrm{~g} / \mathrm{m}^{2}$ per day.

In row crops, the NPP of soybean plants was higher than in wide-row crops. In the interphase period of $\mathrm{BBCH} 13-61$, the difference was 0.403 and $0.858 \mathrm{~g} / \mathrm{m}^{2}$ per day at 45 and $70 \mathrm{~cm}$ row spacing's, respectively. Over time, the difference gradually decreased, dropping down to its minimum in the period of $\mathrm{BBCH} 77-92$, with the difference of 0.218 and $0.508 \mathrm{~g} / \mathrm{m}^{2}$ per day, at rows of 45 and $70 \mathrm{~cm}$, respectively.

Increasing the seeding rate from 0.8 to 1.2 million pcs./ha contributed to an increase in NPP. Over the period of BBCH 13-61, the difference amounted to $0.433 \mathrm{~g} / \mathrm{m}^{2}$ per day; over the period of $\mathrm{BBCH} 61-67$, the difference increased to $0.317 \mathrm{~g} / \mathrm{m}^{2}$ per day, and over the period of $\mathrm{BBCH} 67-77$, the increase was up to $0.317 \mathrm{~g} / \mathrm{m}^{2}$ per day. After that, the difference gradually decreased, and in the period of $\mathrm{BBCH} 77-92$ it was at $0.279 \mathrm{~g} / \mathrm{m}^{2}$ per day.

The results of the correlation analysis demonstrate that the photosynthetic productivity (S, PP and NPP) of soybean plants of the Annushka variety had a strong direct correlation with the amount of precipitation $r=0.738,0.843$ and 0.714 , which was in the range of $51-71 \%$ of the sample $(d=0.509-0.710)$, respectively. The inverse correlation of medium strength was observed with the average air temperature $\mathrm{r}=-0.557 ;-0.657$ and 0.503 , which was within $25-41 \%(\mathrm{~d}=0.253-0.432)$ of the sample (Table 5).

Table 5. The results of correlation analysis of photosynthetic activity of soybean plants ( $S$, PP, NPP) depending on the climate parameters (mean for 2015-2018)

\begin{tabular}{|c|c|c|c|c|c|c|}
\hline \multirow{2}{*}{$\begin{array}{c}\text { Climate } \\
\text { indicators }\end{array}$} & \multicolumn{3}{|c|}{ Variety of soybean Annushka } & \multicolumn{3}{|c|}{ Variety of soybean Baika } \\
\hline & $\mathbf{r}$ & d & Regression equation & $\mathbf{r}$ & d & Regression equation \\
\hline \multicolumn{7}{|c|}{ Leaf surface area $(\mathrm{S})$ of soybean plants, ths. $\mathrm{m}^{2} / \mathrm{ha}$} \\
\hline Precipitation, $\mathrm{mm}$ & 0.738 & 0.545 & $\mathrm{y}=18.686 \mathrm{x}-393.27$ & 0.932 & 0.869 & .44 \\
\hline $\begin{array}{l}\text { rage air } \\
\text { rature, }{ }^{\circ} \mathrm{C}\end{array}$ & -0.557 & 0.310 & $=-0.2023 x+28.317$ & -0.604 & 0.365 & $y=-0.2497 x+28.85$ \\
\hline \multicolumn{7}{|c|}{ Photosynthetic potential (PP) of soybean plants, million $\mathrm{m}^{2} /$ ha per day } \\
\hline Precipitation, & 0843 & 0.710 & $y=25346 x-26836$ & 0.899 & 0.809 & $\mathrm{y}=15$ \\
\hline $\begin{array}{c}\text { Average air } \\
\text { temperature, }{ }^{\circ} \mathrm{C}\end{array}$ & -0.657 & 0.432 & $y=-2.8352 x+27.116$ & -0.803 & 0.645 & $y=-3.0965 x+27.833$ \\
\hline \multicolumn{7}{|c|}{ Net photosynthesis productivity (NPP) of soybean plants, $\mathrm{g} / \mathrm{m}^{2}$ per day } \\
\hline recip & 0.714 & 0.509 & $\mathrm{y}=108.99 x-236.29$ & 0.947 & 0.897 & $\mathrm{y}=71.9$ \\
\hline $\begin{array}{c}\text { Average air } \\
\text { temperature, }{ }^{\circ} \mathrm{C}\end{array}$ & -0.503 & 0.253 & $y=-1.1019 x+26.341$ & -0.547 & 0.299 & $y=-0.9791 x+24.472$ \\
\hline
\end{tabular}

$\mathrm{r}$ - correlation coefficient; $\mathrm{d}$ - coefficient of determination 
A similar pattern has been observed with the soybean plants of Baika variety; however, it had a closer correlation, namely, a very strong direct relationship between precipitation $r=0.932 ; 0.899$ and 0.947 , which was in the range of $87-95 \%$ of the sample $(\mathrm{d}=0.869-0.948)$, respectively. Also, the average feedback was observed with the average air temperature $\mathrm{r}=-0.604 ;-0.803$ and -0.547 , which was in the range of $30-65 \%$ of the sample $(d=0.299-0.645)$.

\section{Conclusions}

As a result of research, an intensive increase in the leaf surface of soybean plants before the BBCH 77 phase was found. After that, the death of the lower tier leaves was observed, which caused a decrease in the plants leaf area. Its highest value, close to the optimal one, characterized the Baika variety with $15 \mathrm{~cm}$ row spacing sowing and the seeding rate of 1.2 million pcs./ha - 40.5 ths. $\mathrm{m}^{2} / \mathrm{ha}$. The soybean plants of the Annushka variety were inferior to the Baika variety soybean plants in terms of leaf area. The difference amounted to 6.0 ths. $\mathrm{m}^{2} / \mathrm{ha}$, which was due to the variety-related differences in the structure of the leaf area.

On the average over four years, the highest value of photosynthetic potential (PP) of 2.311 million $\mathrm{m}^{2} /$ ha per day was formed by soybean plants of the Baika variety, which was $28.4 \%$ more than in the Annushka variety. Wide-row sowing methods with 45 and $70 \mathrm{~cm}$ row spacing reduced PP by $5.9 \%$ and $11.3 \%$ compared to row sowing. The sowing rate factor had the least impact on PP; increasing the rates to 1.1 and 1.2 million pcs/ha resulted in an in significant increase in PP $(0.7 \%$ and $2.3 \%)$.

The highest value of NPP, $11.75 \mathrm{~g} / \mathrm{m}^{2}$ per day, or $1.187 \mathrm{~g} / \mathrm{m}^{2}$ per day more than in the Annushka variety, was formed by soybean plants of the Baika variety. Increasing the row spacing up to 45 and $70 \mathrm{~cm}$ caused a decrease in NPP compared to the row sowing method (width $15 \mathrm{~cm}$ ), the difference was $2.3-3.5 \%$ and $7.4-8.5 \%$. Seeding rates increased NPP; the difference was $11.32 \mathrm{~g} / \mathrm{m}^{2}$ per day.

\section{REFERENCES}

[1] Abaev, A. A., Kazachenko, I. G., Xoxoeva, N. T. (2009): The influence of sowing dates on growth, development and productivity of legumes in the forest-steppe zone of RSOAlanya. - Agrar. vestn. Urala. 6(60): 31-33.

[2] Amelin, A. V., Kuznecov, I. I., Chekalin, E. I. (2011): Peculiarities of photosynthesis in the ontogenesis of soybean varieties of different ecological and geographical origin. Vestn. Orel GAU. 3(30): 2-4.

[3] Andreyuk, E. I. (2010): Bioregulation of Microbial-Plant Systems: Monograph. - In: Iutynska, G. A., Ponomarenko, S. P. (eds.) Nichlava, Kiev, Ukraine.

[4] Babych, A. O., Tkachuk, V. M. (2003): The formation of photosynthetic potential and dynamics of net productivity of photosynthesis crops of soybean depending on the variety, precursor and seeding rate. - Ukrain. Black Sea Region Agr. Science 3(23): 194200.

[5] Babych, A. O., Novokhatskyi, M. L., Tkachuk, V. M., Hrabovskyi, O. O. (2003): Features of dry matter accumulation and absorption of photosynthetically active radiation in crops of soybean. - Bull. of the Bila Tserkva St. Agr. Univ. 26: 3-11.

[6] Balbinot, A. A., Procópio, S. O., Debiasi, H., Franchini, J. C., Panison, F. (2015): Sowing in crossed rows in soybean cultivars with determinate growth habit. - J. Semina Ciencias Agr. 36: 1215-1226. 
[7] Baranov, V. F., Ugo, Toro Korrea (2006): Productivity of new varieties of soybean in crops with different row spacing. - Oil Crops. Scientific and Technical Bull. of VNIIMK. 1(134): 53-57.

[8] Borovoj, E. P., Belik, O. A. (2009): Soybean photosynthetic activity and productivity features during drip irrigation in Nizhneje Povolzhje conditions. - Izvest. of the Lower Volga Agr. Univ. Complex 4(16): 47-52.

[9] Calmes, J., Bensari, M., Viala, G., Gelfi, N. (1988): Les assimilats foliaires du soia et leur utilisation pour le remplissage des graines: influence de 1 "apport d" azote. - Inform. Techn. Centre Techn. Interprof. Oleagineux Metrop. 105: 3-8.

[10] Caulfield, F., Bunce, J. (1988): Comparative responses of photosynthesis to growth temperature in soybean (Glycine max (L.) Merrill) cultivars. - Canad. J. Plant Sc. 68(2): 419-425.

[11] Chuprina Y. Y., Klymenko, I. V., Havva, D. V., Golovan, L. V., Buzina, I. M., Titova, A. Y., Mikheev, V. H., Zabrodina, I. V., Stankevych, S. V. (2020): The level of adaptability of perspective samples of soft and durum spring wheat in Ukrainian forest-steppe. Ukrainian Journal of Ecology 10(6): 12-22. DOI: 10.15421/2020_251.

[12] Chuprina Y. Y., Klymenko, I. V., Belay Y. M., Golovan, L. V., Buzina, I. M., Nazarenko, V. V., Buhaiov, S. M., Mikheev, V. H., Laslo, O. O. (2021a): The adaptability of soft spring wheat (Triticum aestivum L.) varieties. - Ukrainian Journal of Ecology 11(1): 267272. DOI: 10.15421/2021_239.

[13] Chuprina Y. Y., Klymenko, I. V., Golovan, L. V., Buzina, I. M., Belay, Y. M., Mikheev, V. H., Nazarenko, V. V., Vynohradenko, S. O., Khainus, D. D. (2021b): Variability of morphological markers and vegetation period of spring wheat samples of different ecological and geographical origin. - Ukrainian Journal of Ecology 11(2): 241-248. DOI: 10.15421/2021_106.

[14] Cox, W., Cherney, J. H. (2011): Growth and yield responses of soybean to row spacing and seeding rate. - Agronomy J. 103(1): 123-128.

[15] Cunha, A. R., Volpe, C. A. (2010): Radiometric relationships in the upper third of the coffee canopy. - Bragantia 69: 263-271.

[16] Didora, V. H., Baranov, A. I., Stupnitska, O. S. (2013): Formation of the photosynthetic device of soy depending on norms and crops terms in the conditions of polesye of Ukraine. - Visn. Sumskoho Nat. Agr. Univ. Ser. Agr. i Biol. 3: 138-141.

[17] Drobitko, O. M. (2007): The productivity of photosynthesis and soybean yield depending on the spatial and quantitative location of plants in the agrocenosis. - Ukrain. Black Sea region agr. Science 2: 240-245.

[18] Dzhemesiuk, O. V., Novytska, N. V., Svystunova, I. V. (2015): Influence of fertilizing on dynamics of the formation of soybean leaf surface. - Visn. Zhytomyrskoho Nat. Agr. Univ. 2(50): 207-212.

[19] Dziubailo, A. H., Myhal, I. B. (2011): The formation of productivity of soybean varieties depending on norms of sowing of seeds, fertilizers and inoculations. - Feeds and Feed Production 69: 129-132.

[20] Ermantraut, E. R., Prysiazhniuk, O. I., Shevchenko, I. L. (2007): Statistical Analysis of Agronomic Study Data in the Software Suite Statistica 6.0. Guidelines. - PoligrafConsulting, Kiev, Ukraine.

[21] Fontana, D. C., Alves, G. M., Roberti, D., Moraes, O. L., Gerhardt, A. (2012): Estimation of photosynthetically active radiation absorbed by soybean culture using data from the Modis sensor. - Bragantia 71: 563-571.

[22] Golovan, L. V., Klymenko, I. V., Stankevych, S. V., Vasylieva, Y. V., Chupryna, Y. Y. (2019): The inheritance of economically valuable features in the intraspecific hybridization of bean (Phaseolus L). - Ukrain. J. of Ecology 9(2): 156-169.

[23] Gureeva, E. V., Xramoj, V. K. (2009): The seeding rate and production process of soybean varieties in the Non-Chernozem zone. - Bull. of the South Ural St. Univ. Series "Educational Sciences" 1: 60-62. 
[24] Hikosaka, K., Terashima, I. (1995): A model of the acclimation of photosynthesis in the leaves of C3 plants to sun and shade with respect to nitrogen use. - Plant, Cell \& Environment 18: 605-61.

[25] Ivebor, L. U. (2006): The influence of growth stimulants on photosynthetic activity, accumulation and distribution of solids in soybean plants. - Oil Crops. Scientific and Technical Bull. of VNIIMK. 2(135): 110-114.

[26] Kazachenko, I. G. (2010): The optimum sowing dates for promising soybean varieties in the Forest-Steppe zone of RSO-Alania. - Proceedings of Gorsky St. Agr. Univ. 47(1): 3134.

[27] Kizilova, E. G. (1974): The Different Quality of Seeds and Its Agronomic Value. Urozhay, Kiev, Ukraine.

[28] Kokubun, M. (1988): Design and evaluation of soybean ideotypes. - Bull. Tohoku Nat. Agr. Expres. Stat. Morioka 77: 77-142.

[29] Leshhenko, A. K. (1962): The Soybean Culture in Ukraine. - Urozhay, Kiev, Ukraine.

[30] Medvedeva, Z. M., Babarykina, S. A. (2011): Features of the formation of soybean productivity in Western Siberia. - Bull. of Novosibirsk St. Agr. Univ. 2(18): 19-23.

[31] Meier, U. (2001): Growth Stages of Mono and Dicotyledonous Plants. BBCH Monograph. 2nd Ed. - Federal Biological Research Centre for Agriculture and Forestry, Bonn.

[32] Mikheev, V. G. (2012): The influence of regulators of growth and inoculation of seeds on productivity of photosynthesis of soybean crops. - Center for Science Provis. of Agr. in the Kharkov Region 13: 172-179.

[33] Mikheev, V. G. (2014): Photosynthetic productivity of soybean depending on sowing methods in the eastern part of the left-bank forest-steppe of Ukraine. - Center for Science Provis. of Agr. in the Kharkov Region. 16: 138-145.

[34] Miyazawa, S. I., Satomi, S., Terashima, I. (1998): Slow leaf development of evergreen broad-leaved tree species in Japanese warm temperate forests. - Annals of Botany 82(6): 859-869.

[35] Mizerna, N., Nosulia, A. (2016): The soybean crops: present - future. - Propozytsya 10: $40-42$.

[36] Myhal, I. B. (2011): The formation of soybean productivity depending on biological features of a grade, norms of sowing of seeds and level of mineral food in the conditions of the Western Forest-Steppe. - Dis. ... Cand. S.-kh. Sciences: 06.01.09. Vinnytsia, Ukraine.

[37] Nichiporovich, A. A., Stroganova, L. E., Vlasova, M. P. (1969): Photosynthetic Activity of Plants in Crops. - Moscow, USSR.

[38] Ogurtsov, E. (2008): Soybeans in the Eastern Forest Steppe of Ukraine. Monograph. Kharkiv, Ukraine.

[39] Ogurtsov, E., Mikheev, V., Belinsky, Y., Klymenko, I. (2016): Adaptive Technology of Soybean Cultivation in the Eastern Forest Steppe of Ukraine. Monograph. - Kharkiv, Ukraine.

[40] Ono, K., Nishi, Y., Watanabe, A., Terashima, I. (2001): Possible mechanisms of adaptive leaf senescence. - Plant Biology 3(3): 234-243.

[41] Procópio, S. O., Balbinot Junior, A. A., Debiasi, H., Franchini, J. C., Panison, F. (2014): Semeadura em fileira dupla e espaçamento reduzido na cultura da soja. - Revista Agro@mbiente On-Line 8: 212-221.

[42] Purcell, L. C., Ball, R. A., Reaper, J. D., Vories, E. D. (2002): Radiation use efficiency and biomass production in soybean at different plant population densities. - Crop Science 42(1): 172-177.

[43] Rahman, M. M., Hossain, M., Bell, R. W. (2011): Plant density effects on growth, yield and yield components of two soybean varieties under equidistant planting arrangement. Asian J. of Plant Sciences 10: 278-286. 
[44] Raniele, S., Itamar, T., Elton, R., Alessandro, S. (2016): Soybean morphophysiology and yield response to seeding systems and plant populations. - Chilean J. Agric. Res. 76(1): 3-8.

[45] Ribeiro, A. B. M., Bruzi, A. T., Zuffo, A. M., Zambiazzi, E. V., Soares, I. O. (2017): Productive performance of soybean cultivars grown in different plant densities. - Ciência Rural. 47: 81-89.

[46] Rozhkov, A. O., Puzik, V. K., Kalenska, S. M., Puzik, L. M., Popov, S. I. (2016): An Agronomy Pilot Case: Educ. Guide: in 2 Books. Book. 1. Theoretical Aspects of the Case Study. - Maidan, Kharkiv, Ukraine.

[47] Rozhkov, A. O., Karpuk, L. M., Puzik, L. M., Mikheieva, O. O., Kulyk, M. I., Filon, V. I., Shevchenko, M. V., Romanov, O. V., Herman, L. V., Mikheiev, V. G., Shmaiun, D. S. (2021): Crop capacity and quality of soybean grain depending on seed sowing rate and width of inter-rows. - Psychology and Education 58(4): 3282-3299.

[48] Sauer, T. J., Singer, J. W., Prueger, J. H., DeSutter, T. M. (2007): Radiation balance and evaporation partitioning in a narrow-row soybean canopy. - Agr. and Forest Meteorology 145(3-4): 206-214.

[49] Shepilova, T. P., Petrenko, D. I. (2017): Influence of seeding methods and rates on the growth and development of. - Bull. of Uman Nat. Univ. of Horticulture. 1: 74-77.

[50] Sidorovich, V. P. (2002): The crops of soybean: opportunities and challenges. - Feed Production 10: 24-26.

[51] Silva, W. B., Petter, F. A., Lima, L. B., Andrade, F. R. (2013): Desenvolvimento inicial de Urochloa ruziziensis e desempenho agronômico da soja em diferentes arranjos espaciais no cerrado Mato-Grossense. - Bragantia 72: 146-153.

[52] Sims, D. A., Luo, Y., Seemann, J. R. (1998): Importance of leaf versus whole plant $\mathrm{CO}_{2}$ environment for photosynthetic acclimation. - Plant, Cell \& Environment 21/11: 11891196.

[53] State Statistics Service of Ukraine (2019): http://www.ukrstat.gov.ua. - State Statistics Service of Ukraine.

[54] Tikhonenko, D. G., Degtyarev, Y. V. (2016): Soil cover of the research field of "Rogan hospital." - Kharkov Nat. Agr. Univ. them. V. V. Dokuchaev. Series "Soil Science, Agrochemistry, Agriculture, Forestry, Soil Ecology” 2: 5-13.

[55] Tishchenko, L. (2015): Technological Maps of Cultivation of Crops: Qty. Monograph. In: Tishchenko, L. M., Korniienko, S. I. (eds.) Generous Manor Plus, Kharkiv, Ukraine.

[56] Tolmachev, M. V., Sinegovskaja, V. T. (2009): The influence of cultivation techniques on the photosynthetic activity and productivity of soybean varieties. - Vesn. of Altai St. Agr. Univ. 12(62): 5-8.

[57] Tretjakov, N. N., Karnauhova, T. V., Panichkin, L. A. (2003): The Practical Work by Plant Physiology. - Kolos,Moscow.

[58] Yilmaz, N. (2003): The effects of seed rate on yield and yield components of soybean (Glycine max L. Merill). - Pakistan J. of Biolog. Sciences 6: 373-376.

[59] Zherebko, V. M., Cherneha, T. O., Zherebko, Y. V., Konopolskyi, O. P. (2003): The impact of protection of soybean crops from weeds on its productivity in the Forest-Steppe of Ukraine. - Ukrain. Black Sea Region Agrarian Science 3(23): 44-49. 